\title{
Competitive Team-based Learning vs. Reciprocal Teaching of Reading: A Study in Reading Classes
}

\author{
Fatemeh Salari \\ Golrizan Language Institute in Mashhad, Iran \\ Seyed Mohammad Hassan Hosseini \\ Mashhad Rooyan Research Centre, Iran
}

\begin{abstract}
This study was an experimental investigation on the effects of a new innovative approach to ELT/Education namely Competitive Team-Based Learning (CTBL), developed by Hosseini (2009, 2019) at Mashhad Rooyan Research Center in Iran, and Reciprocal Teaching of Reading (RTR), developed by Palinscar, at the University of Michigan and Brown (1985), at the University of Illinois at Urbana-Champaign, on the reading comprehension of Iranian EFL intermediate students. See the introductory 17-minute video to CTBL at https://youtu.be/cPtOUaIkJlk or at http://www.aparat.com/v/i32tK. After administering Interchange placement test to a total population of 75 , and after ensuring that the participants were homogenous and at intermediate level, sixty students were selected, based on their scores in the pretest. Then, they were randomly assigned to two experimental groups - thirty per group. Each class was divided into seven teams of four - the two remaining students in each class worked in pairs. Before the experiment, the researchers conducted the Interchange reading test. In the course of experimentation, while the first experimental group was instructed via RTR method of CL, the second experimental group was instructed via Hosseini's approach to (language) teaching (i.e., CTBL). At the end of the study, the reading comprehension test (posttest) was used to assess the probable progress in the reading comprehension ability of the students. Independent samples T-test illustrated statistical significance at $\mathbf{P} \leq \mathbf{0 . 0 5}$ level that proved the superiority of CTBL over RTR on the participants' reading comprehension achievements. Suggestions to researchers have been put forward at the end of the present article.
\end{abstract}

Index Terms - competitive team-based learning, reciprocal teaching of reading, reading comprehension

\section{INTRODUCTION}

As an effective means of communication in today world context of globalization, reading could also greatly contribute to the quality of the language one acquires/learns. Iranian college and graduate students need effective reading skills to comprehend a large number of reading materials from various sources related to their studies which are engulfing them. For Iranian high-school students, as English foreign language (EFL) learners, reading is even more important. This is due to the fact that they have to be very competitive in the national universities' entrance examination. In addition, high-school students need to improve their English reading comprehension abilities to more advanced level because of the demanding expectations for academic success in all areas of learning.

In spite of the significant importance of English, English Language Teaching (ELT), particularly in reading comprehension classes/courses, has not been a success in Iran until now (Hosseini, 2012). Some difficulties including large size of classes, limited reading strategies, and particularly the methods of teaching reading comprehension in Iranian classrooms causes the Iranian students' English reading ability does not reach a very high level of proficiency.

Hosseini (2007, cited in Jahanbazian, 2015) proposes the idea that the teaching methods and approaches Iranian educators avail themselves of in the course of teaching English language play a more noteworthy role in this fiasco. He argues that in spite of the considerable developments in the field of ELT, Iranian teachers as well as most of teachers from other parts of the world are still applying the traditional methods and approaches in their language classes. According to Hosseini majority of Iranian teachers are using a hybrid of grammar translation methods and audio lingual methods for the purpose of teaching English language in their classes. The fact is that the mechanisms underlying such classes do not have the potentiality to engage all of the students in the process of language learning. Furthermore, the pivotal role of language learning strategies has been greatly ignored in Iranian language classes.

It is in such a context that in recent years, the pendulum in language education is shifting towards learner-centered models and approaches. This shift signals a new era in which the significance of language learning strategies also is prioritized. A promising method to traditional teaching of reading is Cooperative Learning (CL). CL could serve as an alternative way of teaching for promoting reading abilities of students (Gomleksiz, 2007; Ning, 2011). Prior research also suggests that CL has significant effects on developing students' reading skills (Pattanpichet, 2011). The common belief is that in cooperative learning settings students are more active and are encouraged to take more responsibility for their learning. But CL is a general term that refers to some teaching methods where students work in groups on a certain activity 
in order to maximize one another's learning and to achieve certain shared learning goals (Johnson, Johnson, \& Smith, 1998, cited in Jahanbazian 2015). Like many other parts of the world, however, in Iran too English reading instruction within the framework of CL has not been tried yet at the intermediate level particularly when it comes to different CL methods such as Competitive Team-Based Learning (CTBL) and Reciprocal teaching of Reading (RTR).

\section{A. Statement of the Problem and Purpose of the Study}

Reading comprehension is one of the most important skills to be developed and enhanced in language learners. It is, perhaps, in such a context that to comprehend appropriately is the main goal of TEFL in Iran. Nevertheless, it seems that a considerable number of even the students who graduate from universities are not still satisfied with their reading performances. This calls for immediate action to be taken. As it will be hypothesized in this research study, one of the main influential factors in our fiasco, in TEFL, in Iran, relates to the contexts of our classes occasioned by our approaches to teaching. It is a known fact that students in our present traditional contexts of learning are passive and are not willing to take responsibility for their own learning in the course of learning. And such behaviors contribute to their failure.

According to researchers like Jahanbazian (2015), there is no doubt today that CL methods are more effective than the traditional methods in improving reading performance of learners. As it will be clarified, the effects of CTBL and RTR methods of CL on students' reading comprehension have been repeatedly demonstrated and confirmed by studies conducted in L1 and L2 learning environments. However, studies on this area with EFL students in Iran are none and far between. Thus further investigation to examine whether the positive effect of CTBL and RTR also holds true for improving Iranian students' reading comprehension, still calls for empirical validation.

In the present study, as such, the researchers have tried to evaluate the effectiveness of CTBL and RTR on the reading comprehension of Iranian intermediate students. The researchers decided to compare CTBL with RTR as they think that, in comparison to other methods of CL, these methods are the most effective methods particularly for reading classes.

\section{B. Significance of and Justification for the Study}

This study considers an issue which has been ignored by researchers particularly in Iran. The results of this study would assist (language) educators increase their knowledge of particularly CTBL, which is a modern seminal approach to ELT/Education (Hosseini, 2019). As Hosseini confirms, the significance of CTBL for language classes refers to its focus upon systematic implementation of teamwork and discussion, which are of paramount importance for language learning. Teamwork and discussion contribute to direct and indirect transference of language learning strategies, social skills and learners' dispositions. Also, the value of RTR for language classes refers to the fact that it focuses on direct and explicit presentation of four main reading strategies in group work oriented learning environments.

Most importantly, the present study investigates the effectiveness of two Western oriented educational approaches in an Asian context, in language classes in Iran. As researchers like Jahanbazian (2015) and Akbarzadeh (2017) have confirmed, in spite of the large amount of research on the effectiveness of methods of CL in the West, there has been few researches on their effectiveness in non-Western academic environments, particularly in relation to EFL settings. This study would answer the question 'Whether CTBL and RTR would be effective in Iran?' and if yes, to what extent? The researchers hope that their findings would also encourage and help Iranian language educators to implement CL methods in their classrooms for the development of particularly reading performance of Iranian students. Educational policy makers, educationalists, researchers, syllabus designers, and material developers all throughout the world could also avail themselves of the results of this study.

\section{Research Question and Hypothesis}

This study was, thereby, an attempt to compare the effects of CTBL and RTR on the reading performance of Iranian intermediate students. The purpose of the present study was to answer the following question:

RQ: Was there any significant difference between the effects of CTBL and RTR teaching methods on the intermediate EFL students' reading performance?

Based on the above question, the null hypothesis was formulated as under:

H0: There would be no significant difference between the effects of CTBL and RTR teaching methods on the intermediate EFL students' reading performance.

\section{REVIEW OF LITERATURE}

A number of researches have been done to investigate the effectiveness of CL methods in developing students' reading skills.

\section{A. Some Studies Related to the Effectiveness of RTR}

Pearson and Fielding (1991) believe that teaching comprehension strategies is effective particularly for students who show poor comprehension. In their over a five-week period study, Westera and Moore (1995) showed that students who had 12 to 16 reciprocal teaching sessions gained, on average, more in tested reading comprehension. In this study $95 \%$ of the extended reciprocal teaching students showed gains in comprehension, compared to $47 \%$ of students in the short 
reciprocal teaching group and $45 \%$ of the students in the control group.

In his comparative study, Alfassi (2004) hypothesized that RTR method of CL would have greater effects on students English reading comprehension in their language courses. Therefore, two classes of good readers were assigned to two groups by random: the experimental group (RTR) included 29 subjects, and the control group included 20 participants. Both groups had pre-, throughout, and post- intervention and maintenance testing was completed. At the end of the study it was found that the experimental group significantly improved as both experimenter-developed and standardized testing showed significant changes between pre- and post-testing. Therefore, it was concluded that RTR was effective for English Language arts curriculum.

In 2003, Clark carried out a 5-week research study to investigate the effect of reciprocal teaching on adult high school students' reading comprehension. Fifteen students participated in the study. Group discussions, written assignments, and surveys of the students' opinions on reciprocal teaching were instruments in this study. The results from the surveys exhibited that forty of the students believed that reciprocal teaching improved their reading comprehension and ninety of them believed they gained benefits from using reciprocal teaching and preferred it to traditional instruction.

In another study, Konpan (2006) compared RTR with the Communicative Language Teaching (CLT) on $12^{\text {th }}$-grade students' reading comprehension. The results showed that the experimental group, who were taught through RTR, improved their English reading comprehension abilities more significantly than the control group (i.e., the group who was instructed through the CLT) at 0.05 level. Therefore, the superiority of RTR over the CLT was confirmed.

In his one-group experimental design research study, Wisaijorn (2003) examined the effects of RTR on reading comprehension of 34 university students of English for Academic Purposes. He used a pretest, a posttest, and a follow-up reading comprehension test; a pre-questionnaire, a post-questionnaire, and a follow-up questionnaire; checklists; and journals. The results exhibited that RTR was more effective in improving the students' reading ability. Moreover, the students exhibited further gains in reading comprehension in the follow-up test compared to the results from the post-test completed at the end of the training.

Rosenshine and Meister (1994) conducted a meta-analysis of sixteen quantitative studies which focused on RTR in higher education. The study showed that reciprocal teaching was most effective for older students as well as those with poor comprehension skills.

Finally, as Fillenworth (1995) and Palincsar and David (1990) confirmed, a number of other researches has been done on the effectiveness of RTR on primary and college different levels and groups of students ' reading abilities. The results of these studies also showed the positive effects of RTR on the participants' reading comprehension abilities.

\section{B. Some Studies Related to the Effectiveness of CTBL}

As this researcher (Hosseini, 2019) explicates, a number of researches have illustrated the significance and effectiveness of his instructional approach, Competitive Team-Based Learning (CTBL). In his MA research study, Hosseini (2000) compared the effectiveness of his own approach (CTBL) with the Traditional Lecture Method (TLM). He found significant results for the effectiveness of CTBL in improving the reading comprehension of Iranian high school students. Also, he found that his approach contributed to the development of reading comprehension abilities of lower performers more effectively than the TLM.

This researcher's PhD research study (Hosseini, 2009, cited in Jahanbazian, 2015), which was a comparative empirical research study sought to explore and examine the complex effects of his educational innovation, CTBL, with Learning Together and the Traditional Lecture Method (TLM) on Iranian and Indian EFL/ESL undergraduate learners': (a) reading comprehension in English, (b) language learning strategies, (c) attitudes towards English language learning and the select teaching methods, and (d) retention of information. All these objectives were addressed with respect to different-level achievers of the target groups with the help of field studies and experiments in Iran and India. It should be mentioned that Learning Together or Cooperative Group-Based Learning (CGBL) method has been developed by Johnson and Johnson at the University of Minnesota in the USA.

It became evident from the analysis of the data gathered that CTBL and CGBL served to (a) increase acquisition of texts contents, (b) widen repertoire of language learning strategies, (c) generate positive attitudes, and (d) improve retention of information, on the part of the target groups more significantly than the TLM. (Hosseini, 2014) Further analysis of the data revealed that whereas CGBL was substantially more effective in developing the reading skills of the participants, CTBL was more successful in developing their metacognitive and affective strategies. It was likewise noted that CTBL facilitated the participants' long-term retention of information or their depth of understanding of the texts contents more effectively than CGBL. The results also indicated that it was CGBL, rather than CTBL, that was more successful in Iran. But, in India, it was CTBL.

In another study, this researcher (Hosseini, 2012b) found that CTBL contributed to the language proficiency of Iranian EFL college seniors more effectively than Structured Academic Controversy method of Johnson brothers at the University of Minnesota in the USA. Also in 2014, in another study, he compared the effectiveness of his method with Group Investigation, developed by Sharan and Sharan (1992) at Tel Avive University, in Israel, with reference to the language proficiency of Iranian EFL intermediate students. This researcher found that his method was more effective in promoting the language proficiency of Iranian EFL intermediate students.

In her study, Jahanbazian (2015) intended to look and compare the possible effects of CTBL with Learning Together (LT) - the most popular method of Cooperative Learning (CL) -- on oral performance of Iranian EFL intermediate 
students. She also wanted to measure the participants' attitudes towards language learning, individualistic class structure, CL, and the selected methods before and after the study. The results of the study showed that CTBL had a more significant effect on improving the oral performance of Iranian intermediate students. Analysis of the quantitative questionnaire results confirmed that there was more tendency towards supporting the implementation of cooperative strategies. More specifically, the participants had more positive attitudes towards CTBL rather than LT.me

Akbarzadeh's (2016) study was an experimental investigation on the effects of CTBL and Student Teams Achievement Divisions (STAD), developed by Slavin and associates (1977) at Johns Hopkins University, in the US, on the reading comprehension of Iranian EFL intermediate students. After conducting an IELTS Reading test to a total population of 75, sixty students were selected, based on their scores in the pretest. Then they were randomly assigned to control and experimental groups - thirty per group. Each class was divided into seven teams of four - the two remained students in each class worked in pairs. The control group was instructed via STAD technique, which is a well-known technique of cooperative learning, while the experimental group were instructed via this researcher's approach to (language) teaching (i.e., CTBL). The reading comprehension test (posttest) was used at the end of the study to assess the probable progress in the reading comprehension ability of the students. The results of the study confirmed the significant effects of CTBL on the participants' reading comprehension achievement.

In another study, Salimi Bani (2017) studied the effect of CTBL and Cooperative Integrated Reading and Composition (CIRC) on the reading comprehension of Iranian intermediate EFL learners. She found significant results which proved the superiority of CTBL over CIRC in improving the reading comprehension of Iranian intermediate EFL learners.

And finally, Salari (2018) studied the effect of CTBL vs. Reciprocal Teaching of Reading (RTR) ), developed by Palinscar, at the University of Michigan, and Brown (1985), at the University of Illinois at Urbana-Champaign, on reading comprehension ability of Iranian EFL learners. She also tried to gage the attitude of the participants towards these methods before and after the study. In her study, after administering Interchange placement test to a total population of 75, and after ensuring that the participants were at the intermediate level and that they were homogenous, sixty students were selected, based on their scores in the pretest. Then, they were randomly assigned to two experimental groups - thirty per group. Each class was divided into seven teams of four - the two remaining students in each class worked in pairs. Before the experiment, we conducted the Interchange reading test and the questionnaire. In the course of experimentation, while the first experimental group was instructed via RTR method of CL, the second experimental group was instructed via this researcher's method of (language) teaching (i.e., CTBL). At the end of the study the questionnaire was applied once again. The reading comprehension test (posttest) was also used to assess the probable progress in the reading comprehension ability of the students. The results on independent samples T-test verified the significant impact of CTBL on the participants' reading comprehension achievements. That is, CTBL was more effective than RTR in improving the reading comprehension ability of Iranian EFL intermediate students. It was also found that the participants had developed more positive attitudes towards CTBL.

Despite the abundance of research findings that verifies the advantage of RTR and CTBL over other methods of teaching, no research, to date, has essayed to directly investigate and compare the effectiveness of RTR and CTBL particularly in reading courses in Iran. This research study has come to address this lacuna in the related literature.

\section{METHOD}

Participants of this study were sixty Iranian intermediate EFL learners studying in Golrizan Language Institute in Mashhad, Iran. They were in two separate classes, including male learners, ranging in age from sixteen to twenty-one. They were all homogeneous with regard to age, exposure to English, and educational background. All of the participants were native speakers of Persian and for this reason, Kurdish and Turkish people were discarded. They were using English as a foreign language for general purposes. They had studied English for six years until the time the experiment was conducted.

Two experimental classes were assigned. One class conducted through RTR and another one through CTBL, each including 30 subjects. The students in the RTR class were allowed to build their teams of three or four members based on their interests. But the students in CTBL class were divided into seven heterogeneous teams based on their performance on the placement test. In other words, each team, in CTBL class, consisted of four members: (a) one learner with a high placement test score, (b) the two others with average placement test scores, and (c) another with a low placement test score. As noted, the placement test was also used to confirm the homogeneity of two experimental groups.

\section{A. Instrumentations}

The main text book which was used in this research was 3rd edition of Interchange 3 (Intermediate) by Jack C. Richards with Jonathan Hall and Susan Proctor (2005). This textbook is used in Golrizan Language Institute in Mashhad, Iran, for intermediate learners and it consists of 16 units. The main purpose of this book is to integrate grammar, pronunciation, vocabulary, listening, speaking, reading and writing. Every unit of this book also contains a reading comprehension text, which was focused upon in the experimental groups in the present research study.

The Interchange Placement Test 
The Interchange placement test was administered at the initial stages of the present research study. This test was applied to demonstrate the level of the participants and homogenization. The participants were tested in order to have two homogenized groups of 30 participants each, based on their scores in the pretest. Sixty learners, from among 75 learners, who scored within one standard deviation above and below the mean, were selected. They were then divided into 2 groups.

The reading section of Interchange placement test was also used to check the reading comprehension of the participants of this study before (pre-test) and after (post-test) the experiment. The same test was given after the study, after a-16-session practice, to see the effects of CTBL and RTR on two experimental groups. The test was similar both in format of the questions and their level for the two groups. The test consisted of 3 sections with a total of 70 questions:

Part 1: The Listening Section

Part 2: The Reading Section

Part 3: The Language Use Section

Learners had 50 minutes to answer the questions. The reason for using Interchange placement test in the present study refers to the fact that it is internationally valid, reliable and easy to administer.

It should, however, be mentioned that item facility and item discrimination has already been calculated for this test. The reliability of the test was found as high as 0.92 . As a result of item analyses, no item was discarded.

\section{B. Procedures}

The placement test was administered to 75 students, in the first session, in order to homogenize the participants according to their language proficiency levels. Sixty students who were nearly at the midpoint were selected, on the basis of the information obtained. To put it another way, very high or too low scores on the test were rejected, which in its turn contributed to the elimination of the effect of statistical regression. The selected participants served the study for a whole academic semester that included 18 sessions of 90 minutes each.

The researchers assigned the participants to the two experimental groups (i.e., CTBL and RTR) randomly. They did not let the population know the fact that an experiment was being conducted in order to minimize the reactive effect of the experimental procedure.

Students were ranked based on their performance and then cooperative groups were formed. In each class at intermediate level, the seven students who scored highest on the placement test were identified as high achievers and the seven students who scored lowest were considered as low-achievers. The remained 16 students were identified as average-achievers.

At this stage, the researchers conducted the pre-test and started the experiment. While in the RTR class, the students were permitted to shape their own teams of three to four members based on their interests, in the CTBL class, the students were assigned to seven teams of one high-achiever, one low-achiever and two average-achievers each. The reminded two students worked in pairs. The reason for this type of team building in CTBL class was that it provided opportunities for learners to peer-tutor and help each other to complete the shared learning goals. After grouping the students, in RTR and CTBL groups, the goals of the experiment and the class management techniques were explicated to the both classes.

Both the classes had the same curriculum, the same instructor and the same schedule of instruction in the course of experimentation. The difference was that while the RTR class experienced a method of presentation that focuses upon explicit teaching of four main reading strategies namely predicting, questioning, summarizing, and clarifying, the participants in the CTBL class experienced systematic teamwork and discussions through which they learned/acquired learning strategies directly and indirectly.

\section{Reciprocal Teaching of Reading and Reading}

As regards teaching a text, in a real classroom situation, in RTR class, having activated students' minds on the topic through different techniques, the teacher introduced the text. To illustrate how the implementation of each of the aforementioned strategies helped students in the comprehension of the passage, the teacher modelled her own process of comprehending of the first paragraph of the text. She did it by thinking the process aloud. Through this technique, students learned the target strategies - the strategies that the teacher had already planned to teach. Students were then given the opportunity to try to follow the same procedure for next paragraphs in their groups so as to internalise and master the strategies. The point is that it was more proficient readers who took the first turns to implement the strategies, by thinking aloud, in order to endow lower performers with more opportunities to better understand the application of strategies. Group members also shared their uncertainties about unfamiliar vocabularies, confusing text passages, and difficult concepts and discussed more practical strategies to be applied for each problem.

\section{Competitive Team Based Learning and Reading}

For a comprehensive understanding of the procedure in classes run through CTBL, see the 17-minute video, prepared by Dr Hosseini, creative of CTBL, at https://youtu.be/cPtOUaIkJlk or at http://www.aparat.com/v/i32tK.As shown in the video, the teaching and assessment process, in CTBL settings, has been designed as it is illustrated in the below figure: 


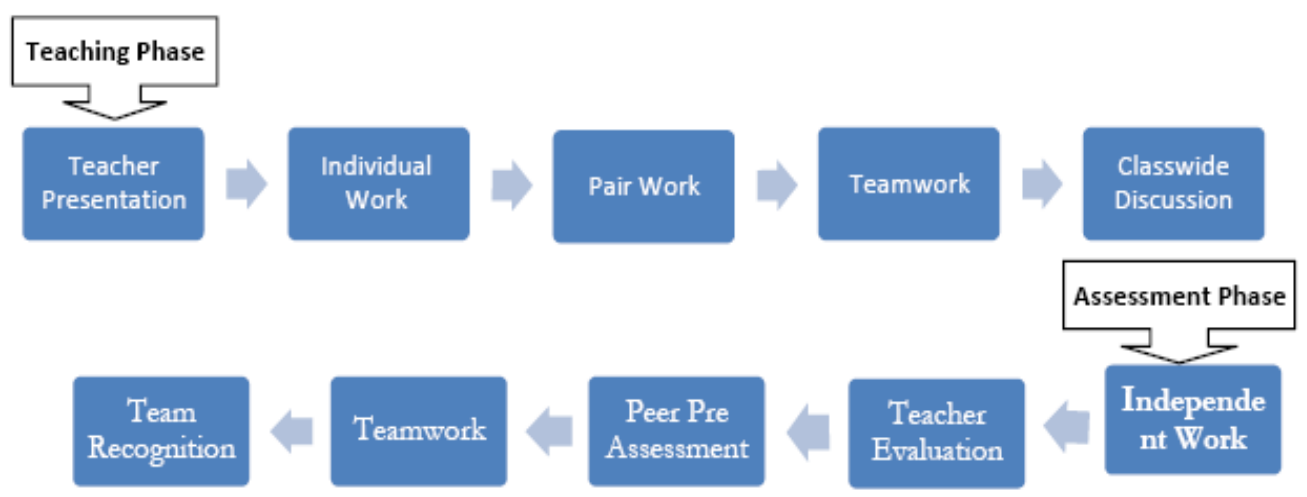

Figure 1. Teaching and assessment process in CTBL class; Adapted from Hosseini, 2012, p. 96

As it is illustrated in the above video/figure, in CTBL class, after the teacher presented the new lesson through different techniques and strategies, team members were required to work individually first. Then they were asked to work in pairs. Later they were encouraged to work as a team - with all their teams' members. And finally, at the end of the class time they had a class-wide discussion. In the following session students had a quiz, which they had to take individually. At the end of given time, the teacher collected some papers for correction and then required students to take the same quiz with their partners - in pairs. After that, the students were required to work on the same quiz in their teams - with all members of their teams. For CTBL's theoretical foundations (i.e., Dr Hosseini's Cognitive SocioPolitical Language Learning Theory as well as his Multiple Input-Output Hypothesis, see Hosseini 2010 and 2019.

\section{Distinguishing between RTR and CTBL}

The researchers have tried to distinguish between RTR and CTBL in the table 1:

TABLE I.

DISTINGUISHING BETWEEN RTR AND CTBL

\begin{tabular}{|l|l|}
\hline RTR & CTBL \\
\hline Less structured & More structured \\
\hline Unsystematic implementation of groupwork & Systematic implementation of teamwork \\
\hline $\begin{array}{l}\text { As a model of teaching does not have its own theoretical } \\
\text { foundations }\end{array}$ & $\begin{array}{l}\text { As an approach has its own theoretical foundations (see } \\
\text { Hosseini, 2019) }\end{array}$ \\
\hline Direct/explicit presentation of four language learning strategies & $\begin{array}{l}\text { Explicit as well as implicit presentation of language learning } \\
\text { strategies }\end{array}$ \\
\hline $\begin{array}{l}\text { The approach to presentation goes through a) teacher presentation, } \\
\text { b) groupwork }\end{array}$ & $\begin{array}{l}\text { The approach to presentation goes through a) teacher presentation, } \\
\text { b) individual work, c) pair work, d) teamwork, e) class wide } \\
\text { discussion }\end{array}$ \\
\hline
\end{tabular}

As opposed to RTR which offers unsystematic implementation of groupwork and emphasizes on direct and explicit presentation of four language learning strategies such as 'summarizing', 'questioning', 'predicting' and 'clarifying', CTBL is a systematic implementation of teamwork that emphasizes explicit as well as implicit presentation of language learning strategies which goes through teacher presentation, individual work, pair work, teamwork and class wide discussion.

\section{Research Design}

The study was a quasi-experimental research which used the two group pre-test treatment post-test design. While the participants' reading performance is the dependent variable of the present study, CTBL and RTR are the two independent variables. As noted, the researchers asked students, in both experimental groups, to take the pre reading test at the initial stage of the study. Regarding the kind of selection of the two groups, randomization process practically assured equivalency in many ways. For example, as both the groups experienced an equal effect of variables like contemporary historical events, maturation, and pre-testing, their effects were controlled. Therefore, the effects of these variables cannot be mistaken in the effect of the treatment as they were equalized. Also, extraneous variables which arise between pre-test and post-test which are known as intersession developments were also balanced out due to the presence of randomized selected groups.

\section{DATA ANALYSis}

The descriptive statistics of the results for the research question are as following:

\section{A. Descriptive Statistics}

\section{Pre-Test Results for Both Groups}

First of all, the means and variances of the two groups in pre-test were calculated. See table 2. 
TABLE II.

PRE-TEST RESULTS FOR BOTH GROUPS

\begin{tabular}{|c|c|c|c|}
\hline Groups & Number & Mean & Variance \\
\hline CTBL & 30 & 17.6 & 8.7 \\
\hline RTR & 30 & 17.76 & 8.5 \\
\hline
\end{tabular}

The means and variances of both groups in pre-test indicated that the two samples had almost the same dispersions from the means. This was suitable for our purpose in the present study.

At the next juncture, to verify the pre-test results on both groups, an independent t-test was used. See table 3.

TABLE III

THE T-VALE FOR THE PRE-TEST OF THE TWO GROUPS

\begin{tabular}{|c|c|c|c|}
\hline $\begin{array}{l}\text { T-value } \\
\text { Critical }\end{array}$ & $\begin{array}{l}\text { Degree of } \\
\text { Freedom }\end{array}$ & $\begin{array}{l}\text { Two-tailed } \\
\text { Probability }\end{array}$ & $\begin{array}{c}\text { T-value } \\
\text { Observed }\end{array}$ \\
\hline 2 & 58 & 0.05 & -0.21 \\
\hline
\end{tabular}

As the value of the calculated $t(-0.21)$ was less than the value of the t-critical (2) at 0.05 level of probability, the researchers concluded that the two groups had little difference.

\section{RTR Group Pre-Test and Post-Test Means}

The means obtained from the pre-test and post-test of the RTR group, which are presented in table 4, indicated that there has been a little progress in this group.

TABLE IV.

RTR GROUP'S PRE AND POST TESTS MEANS

\begin{tabular}{|c|c|}
\hline pre- test mean & post-test mean \\
\hline 17.76 & 21.16 \\
\hline
\end{tabular}

To find out the significance of the above difference a matched t-test was conducted. See table 5.

TABLE V.

PAIRED T-TEST FOR RTR GROUP

\begin{tabular}{|l|c|c|c|c|c|c|}
\hline Group & X1 & X2 & S1 & S2 & D.F. & T-ob. \\
\hline RTR & 16.69 & 20.15 & 2.95 & 5.53 & 28.9 & -6.7 \\
\hline P>0.05 t-critical 2.045 & X2 = posttest mean \\
X1 = pretest mean & S2 posttest standard deviation \\
S1 = pretest standard deviation & T-Ob = T Observed \\
D.F. = Degree of Freedom &
\end{tabular}

As the observed $t$ of -6.7 at a probability level of $\mathrm{P}>0.05$ exceeded the critical $t$ of 2.045 , the researchers concluded that there was significant difference between the RTR group performances on both tests. (See also table 6)

CTBL Group Pre-Test and Post-Test Means

The means gained from the pre-test and post-test of the CTBL group are presented in table 6.

TABLE VI.

PRE-TEST AND POST-TEST MEANS OF CTBL GROUP

\begin{tabular}{|c|c|}
\hline \multicolumn{2}{|c|}{ PRE-TEST AND POST-TEST MEANS OF CTBL GROUP } \\
\hline pre- test mean & post-test mean \\
\hline 16.69 & 24.9 \\
\hline
\end{tabular}

The results of the CTBL group's means on both tests showed a remarkably high difference which supported the positive correlation of CTBL and Iranian EFL intermediate students' reading comprehension.

The researchers conducted another paired t-test in order to ascertain the results. See table 7.

TABLE VII.

PAIRED T-TEST FOR CTBL GROUP

\begin{tabular}{|c|c|c|c|c|c|c|}
\hline \multicolumn{7}{|c|}{ PAIRED T-TEST FOR CTBL GROUP } \\
\hline Group & $\mathrm{X} 1$ & $\mathrm{X} 2$ & S1 & S2 & D.F. & Tob. \\
\hline Exp.G. & 16.99 & 24.7 & 2.91 & 3.92 & 29 & 16.7 \\
\hline \multicolumn{7}{|c|}{ t-critical 2.045} \\
\hline \multicolumn{3}{|c|}{$\mathrm{X} 1=$ pretest mean } & \multicolumn{4}{|c|}{$\mathrm{X} 2=$ posttest mean } \\
\hline \multicolumn{3}{|c|}{$\mathrm{S} 1=$ pretest standard deviation } & \multicolumn{4}{|c|}{$\mathrm{S} 2=$ posttest standard deviation } \\
\hline \multicolumn{3}{|c|}{ D.F. = Degree of Freedom } & \multicolumn{4}{|c|}{$\mathrm{T}-\mathrm{Ob}=\mathrm{T}$ Observed } \\
\hline
\end{tabular}

As shown in the above table, the t-observed (16.7) surpassed the value of t-critical (2.045) at a probability level of $\mathrm{P}>0.05$. This would support the aforementioned hypothesis that CTBL has a significant effect on the reading comprehension of Iranian EFL intermediate students.

Post-Test Results for Both Groups

The two groups' means and variances in post-test were calculated at this stage. See table 8 . 
TABLE VIII.

RESULTS OF POST-TEST FOR BOTH GROUPS

\begin{tabular}{|c|c|c|}
\hline \multicolumn{3}{|c|}{ RESULTS OF POST-TEST FOR BOTH GROUPS } \\
\hline Group & Mean & Variance \\
\hline CTBL & 25.5 & 15.6 \\
\hline RTR & 21.16 & 29.3 \\
\hline
\end{tabular}

The differences between the variances of the two groups showed that the CTBL group remained to be more homogeneous. Moreover, the means presented in table 4.5.1 illustrated significant differences between the two groups. It seemed that the null hypothesis was firmly rejected.

To be sure, the results obtained from the post-test were subjected to an independent t-test. See table 9.

TABLE IX

THE T-VALUE FOR THE POST-TEST OF THE TWO GROUPS

\begin{tabular}{|c|c|c|c|}
\hline $\begin{array}{c}\text { T-value } \\
\text { Critical }\end{array}$ & $\begin{array}{c}\text { Degree of } \\
\text { Freedom }\end{array}$ & $\begin{array}{c}\text { Two-tailed } \\
\text { Probability }\end{array}$ & $\begin{array}{c}\text { T-value } \\
\text { Observed }\end{array}$ \\
\hline 2 & 58 & 0.05 & 16.7 \\
\hline
\end{tabular}

The researchers rejected the null hypothesis as the t-observed of 16.7 surpassed critical $t$ of 2 at a probability level of $\mathrm{P}>0.05$. To put it another way, the independent t-test' results confirmed the positive relationship between CTBL and reading comprehension of Iranian EFL intermediate students.

Now, it can be claimed that in our class' settings, CTBL bears better results than RTR and improves intermediate learners' reading comprehension abilities.

\section{B. Inferential Statistics}

Before continuing our discussions, the researchers review this research study question once more:

RQ: Is there any difference between the reading comprehension performance of the intermediate EFL students who are taught with CTBL and those who are taught with RTR?

The researchers applied a t-student test first to investigate the above research question. But before that, they tested to see whether the two groups were normal with reference to their reading comprehension performances. They also intended to ensure that the two groups' variances were equal. For the former purpose, the researchers applied OneSample Kolmogorov-Smirnov Test. They also evaluated Equality of Variance test.

TABLE X (a)

ONE-SAMPLE KOLMOGOROV-SMIRNOV TEST

\begin{tabular}{|c|c|c|c|}
\hline & & $\begin{array}{l}\text { Reading comprehension } \\
\text { performance in CTBL }\end{array}$ & $\begin{array}{l}\text { Reading comprehension } \\
\text { performance in RTR }\end{array}$ \\
\hline \multicolumn{2}{|l|}{$\mathbf{N}$} & 30 & 30 \\
\hline \multirow{2}{*}{ Normal Parameters ${ }^{\mathrm{a}, \mathrm{b}}$} & Mean & 24.7600 & 28.4643 \\
\hline & Std. Deviation & 4.52111 & 5.18286 \\
\hline \multirow{3}{*}{ Most Extreme Differences } & Absolute & .121 & .158 \\
\hline & Positive & .069 & .111 \\
\hline & Negative & -.120 & -.151 \\
\hline \multicolumn{2}{|l|}{ Kolmogorov-Smirnov Z } & .571 & .772 \\
\hline \multicolumn{2}{|l|}{ Asymp. Sig. (2-tailed) } & .911 & .588 \\
\hline
\end{tabular}

That CTBL group is normal is not rejected in view of the fact that p-value (0.911) in Kolmogorov-Smirnov Test of reading comprehension performance in this group is higher than 0.05. Similarly, that RTR group is normal is not rejected as p-value (0.588) in Kolmogorov-Smirnov Test of reading comprehension performance in this group is higher than 0.05 .

Then, the researchers applied Levene's Test for Equality of Variances in the two groups.

TABLE X (b).

LEVENE'S TEST FOR EQUALITY OF VARIANCES IN CTBL AND RTR GROUPS

\begin{tabular}{|ll|l|l|}
\hline \multirow{2}{*}{} & & Learner's Test for Equality of Variances \\
\cline { 3 - 4 } & $\mathrm{F}$ & Sig. \\
\hline Reading Skill & $\begin{array}{l}\text { Equal variances assumed } \\
\text { Equal variances not assumed }\end{array}$ & .770 & .384 \\
\hline
\end{tabular}

Again, that the variances in the two groups are equal is not rejected since p-value $(0.384)$ in Levene's Test is higher than 0.05 .

Now, with the assumption of the equality of the variances of the two groups, t-student test was conducted the results of which are as below: 
TABLE X (C)

GROUP STATISTICS

\begin{tabular}{|l|l|l|l|l|l|}
\hline & Method & N & Mean & Std. Deviation & Std. Error Mean \\
\hline $\begin{array}{l}\text { Reading } \\
\text { comprehension } \\
\text { performance }\end{array}$ & RTR & 30 & 25.1071 & 4.41663 & .83466 \\
\cline { 2 - 6 } & CTBL & 30 & 28.4643 & 5.18175 & .97926 \\
\hline
\end{tabular}

TABLE X $(\mathrm{d})$.

INDEPENDENT SAMPLES TEST

Independent Samples Test

\begin{tabular}{|c|c|c|c|c|c|c|c|c|c|c|}
\hline & \multicolumn{2}{|c|}{$\begin{array}{lr}\text { Levene's } & \text { Test } \\
\text { Equality } & \text { of } \\
\text { Variances } & \\
\end{array}$} & \multicolumn{7}{|c|}{ t-test for Equality of Means } \\
\hline & & \multirow[t]{2}{*}{$\mathbf{F}$} & \multirow[t]{2}{*}{ Sig. } & \multirow[t]{2}{*}{ t } & \multirow[t]{2}{*}{ df } & \multirow[t]{2}{*}{$\begin{array}{l}\text { Sig. (2- } \\
\text { tailed) }\end{array}$} & \multirow[t]{2}{*}{$\begin{array}{l}\text { Mean } \\
\text { Difference }\end{array}$} & \multirow[t]{2}{*}{$\begin{array}{l}\text { Std. Error } \\
\text { Difference }\end{array}$} & \multicolumn{2}{|c|}{\begin{tabular}{llr}
$95 \%$ & \multicolumn{2}{r|}{ Confidence } \\
Interval of the \\
Difference
\end{tabular}} \\
\hline & & & & & & & & & Lower & Upper \\
\hline \multirow{2}{*}{$\begin{array}{l}\text { Reading } \\
\text { comprehensio } \\
\text { n performance }\end{array}$} & $\begin{array}{l}\text { Equal } \\
\text { variances } \\
\text { assumed } \\
\end{array}$ & .770 & .384 & -2.609 & 54 & .012 & -3.35714 & 1.28671 & -5.93683 & -.77745 \\
\hline & $\begin{array}{l}\text { Equal } \\
\text { variances } \\
\text { not assumed }\end{array}$ & & & -2.609 & 52.678 & .012 & -3.35714 & 1.28671 & -5.93832 & -.77597 \\
\hline
\end{tabular}

The assumption of the equality of the average of reading comprehension performance in the two groups, with the assumption of the equality of the variance of the two groups, is rejected as p-value (0.012) in t-student Test is less than 0.05. Also, as noted in the table, the average of reading comprehension performance in CTBL is higher than the average of reading comprehension performance in RTR. Based on such results, the researchers concluded that CTBL is more effective than RTR in developing reading comprehension performance of students.

\section{DiSCUSSION AND CONCLUSION}

The results of the present study rejected the null hypothesis and confirmed the idea that CTBL is more effective in improving the reading comprehension of Iranian EFL intermediate students. It was found that systematic implementation of teamwork through CTBL, which was also more structured, greatly affected the success of reading courses. It was revealed that much more individual learning/understanding had occurred in the CTBL class than in RTR class. Particularly, lower performers had further benefits in this class.

The results of this study were similar to the findings of Hosseini (2000, 2009, 2012), Jahanbazian (2015), Akbarzadeh (2017), Akinbobola (2009) and Salimi Bani (2017). But the results of this study were not completely in line with the findings of Nederhood (1986) who found no significant results for academic achievement of students in CL classes. Nederhood's study was a meta-analysis of 34 studies, which attempted to find out the effects of CL on reading comprehension, language arts, and mathematics of 1145 middle school students in 114 classrooms. The results of the study corroborates the idea that if Dr Hosseini's approach to ELT/Education is employed thoroughly and systematically, it can significantly improve the achievement of intermediate students' reading comprehension performance.

It is surprising that despite the results of our studies, our classroom practice, particularly here in Iran, is so much oriented toward traditional methods. It is time for the discrepancy to be reduced between what research indicates is effective in teaching and what teachers actually do.

\section{A. Practical Implications}

The importance of CTBL for language classes refers to the fact that it focuses on systematic teamwork. Successful teamwork is helpful to the emergence of different and creative ideas and strategies, which are favorable to the reading comprehension of learners also. Students' reading comprehensions develop meaningfully in CTBL settings as they need to exchange information, strategies and advice in order to succeed in achieving their shared learning goals.

This study provided data that reflects the essentials of our classrooms. The results provided by the present study may be of some help to both theoreticians and practitioners in the field of TEFL/ELT/Education. At the level of theory, our findings confirmed Vygotsky's Zone of Proximal Development (1978) which emphasizes the facilitative role of interaction in learning. The ability to work with others, in competitive environments, which contribute to developing interpersonal skills suffices it enough to implement CTBL in today world classes. Increased interaction in English and easy management of large classes may be other motivating factors for employing CTBL.

\section{Implication for Language Teachers.}

At the level of practice, the results yielded through the study may be helpful to language teachers. Although using new methods is paramount and effective in learning, teachers should not neglect the significant impact of systematic implementation of teamwork on the reading comprehension abilities of their students. More specifically, the researchers suggest language teachers to focus on explicit as well as implicit teaching of reading strategies in CTBL 
interactive environments. The interaction occasioned in such environments brings about many positive results particularly for the implementation and success of their technical innovations. Teachers should be aware that the process of learning is not a smooth one. In other words, their efforts would be in vain if they insist on their traditional chalk and talk system of class management. As Block 1998) also confirms, through the implementation of the traditional method in their classes, teachers are distorting the process of learning by chewing up the text for students and not allowing them to eat on their own.

Since CTBL proved to be useful in actual classroom procedure with EFL Iranian students in the present study, EFL teachers may easily adopt this approach in their reading courses to advance the students' reading abilities. It seems that if teachers try to have a general understanding of CTBL's principles, they can develop a range of tactics which will enable their language classes to become fully bonded, motivated, activated, and engaged in learning in a process - oriented environment. Language teachers should use CTBL in the reading class as it provides situations wherein students learn how to work collaboratively in the context of group discussion for constructing meanings out of the texts. In the process, students' self-regulatory and monitoring skills can develop, producing an autonomous reader.

\section{Implication forMaterial Developers.}

Material developers may incorporate and design more challenging and motivating teaching materials, exercises, and activities which can encourage students to interact with their team members more effectively. This, in turn, helps learners to learn more about learning, increase their understanding and rate of learning, improve their reading abilities, and make more effective transitions to real world settings, where they will draw upon their experiences and skills to communicate, negotiate, build consensus, cooperate, compete and learn with others (Jahanbazian, 2015). Therefore, syllabus designers too should tr y to

a. clarify the common short comings of team activities provided in their textbooks, and modify them in order to enhance the probability of more effective student interaction in classes run through CTBL.

b. increase the quantity and quality of team activities in recent ELT course books.

\section{Implication for Methodologists.}

Methodologists may also take CTBL's benefits into consideration and strongly recommend it to teachers/educators throughout the world for more interesting and of course effective classes. Methodologists should consider the fact that what differentiates CTBL, as a holistic approach, from other CL methods and even CLT refers to the emphasis it puts on the significance of systematic teamwork in competitive environments, as a real world phenomenon. Hosseini (2019) argues that our classes, as fractions of the real world, should prepare students for the real world, the macrocosm. He is of the opinion that as the real world is characterized with competition in environments that are engulfed with socio-political issues, educators should try to increase tomorrow citizenry's socio-political awareness in competitive environments.

\section{B. Suggestions for Further Research}

The researchers suggest language teachers and researchers to compare the effectiveness of Dr Hosseini's approach to (language) teaching with other methods and approaches with regard to other skills and sub skills, rather than reading, in their school as well as university classes. Furthermore, Dr Hosseini (2019) believes that CTBL contributes to critical thinking and creativity of mind more effectively. He is also of the opinion that his seminal approach to ELT/Education contributes effectively to nation building, more civilised societies and eventually modern democracy and world peace, all of which exact more researches:

$D E M O C R A C Y$ is an ideology which above all others prioritizes the paramount importance of humanitarian interpersonal principles and skills in human relationship, without which its practitioners are maimed. We educators must, thus, practice tomorrow citizenry in such norms, principles, and skills, in our mini-democratic lands (classes), if we do not want to continue to give birth to maimed detrimental-to-global-peace societies; if we want to contribute to the overthrow of dictatorial/corrupt regimes, and if we want to transform the present peasant communities into more civilized societies and compassionate civilizations. All of these are of significant importance as they contribute to live, humane, healthy, and civilized societies, and world peace, which is the ultimate dream of humanity in today highly multicultural, incredibly complicated, and of course developmentally competitive world context of globalization. As a more realistic seminal approach to liberal education, Competitive Team-Based Learning (CTBL), the sum-total of my educational life, could serve democracy as a major building block. (Hosseini, 2019, p. 136)

For more comprehensive understanding of CTBL's theoretical foundations and it's salient features which distinguish it from CLT and the present innovative methods and approaches, search Dr Hosseini's Didactic Weapon on the net and watch my 17-minute introductory video or search the title of his approach. You may also see Hosseini, 2012/2018/2019.

\section{ACKNOWLEDGMENTS}

The researchers would like to thank particularly Dr Ghasem Modarresi for his effective contribution, feedback and helpful comments. 


\section{REFERENCES}

[1] Akbarzadeh, M (2017). A study into the effects of 'competitive team-based learning' and'student teams- achievement divisions on the reading comprehension of Iranian EFL intermediate students. Unpublished MA thesis, Islamic Azad University of Roudehen, Iran

[2] Akinbobola, A. (2009). Enhancing Students' Attitude towards Nigerian Senior Secondary School Physics Through the Use of Cooperative, Competitive and Individualistic Learning Strategies. Australian Journal of Teacher Education, 34 (1) 1 - 9.

[3] Alfassi, M. (2004). Reading to learn: effects of combined strategy instruction on high school students. Journal of Educational Research. 97(4), 171-184.

[4] Clark, L. (2003). Reciprocal teaching strategy and adult high school students. Published master research, Kean University, United States. Retrieved September 10, 2015, from http://www.eric.ed.gov.

[5] Fillenworth, L. (1995). Using reciprocal teaching to help at-risk college freshmen study and read. Unpublished doctoral dissertation, University of Minnesota.

[6] Gomleksiz, M. N. (2007). Effectiveness of cooperative learning (jigsaw II) method on teaching English as a foreign language to engineering students (Case of Firat University, Turkey). European Journal of Engineering Education, 32(5), $613-625$

[7] Hattie, J. (2009). Visible learning: A synthesis of over 800 meta-analyses relating to achievement. London: Routledge.

[8] Hosseini, S.M.H. (2000). The Impact of Competitive Team-Based Learning on the Reading Comprehension of Iranian High School Students. Unpublished MA Thesis, Islamic Azad University of Garmsar, Iran.

[9] Hosseini, S.M.H. (2007). ELT in Higher Education in Iran and India: A Critical View. Language in India, 7, 1-11. Retrieved from http://www.languageinindia.com/dec2007/eltinindiaandiran.pdf (accessed on: 24/01/2019).

[10] Hosseini, S.M.H. (2009). Effectiveness of Cooperative Learning Methods: A Study with Iranian and Indian Undergraduate Learners. Unpublished PhD Thesis, Mysore University, India.

[11] Hosseini, S.M.H. (2010). Theoretical foundations of Competitive Team-Based Learning. Canadian International Journal of English Language Teaching 3, $229 \quad-\quad 243 . \quad$ doi:10.5539/elt.v3n3p229. Retrieved from http://www.ccsenet.org/journal/index.php/elt/article/view/7236 (accessed on: 24/01/ 2019).

[12] Hosseini, S.M.H. (2011). http://www.beyondelt.blogfa.com.

[13] Hosseini, S.M.H. (2012a). Beyond the present methods and approaches to ELT/education: The crucial need for a radical reform. Tehran: Jungle Publication.

[14] Hosseini, S. M. H. (2012b). A study of the effects of Competitive Team-Based Learning and Structured Academic Controversy on the language proficiency of Iranian EFL college seniors. The International Journal of Adult Vocational Education and Technology, 3, 100-105. doi: 10.4018/javet.2012100105.

[15] Hosseini, S. M. H. (2014). Competitive Team-Based Learning versus Group Investigation with reference to the language proficiency of Iranian EFL intermediate students. International Journal of Instruction, 7, 176-188.

[16] Hosseini, S.M.H. (2015). Method Engineering: Towards a Strategic Approach to the Empowerment of the Other. International Journal of SYLWAN, 4(2), 159-168.

[17] Hosseini, S.M.H. (2018). Competitive Team-Based Leaning: Beyond current didactic methods. Germany: Lambert Academic Publishing.

[18] Hosseini, S. M. H. (2019). Cognitive Socio-Political Language Learning Theory, Multiple Input-Output Hypothesis and Competitive Team-Based Learning. Theory and Practice in Language Studies, 9(4): 411-423. DOI: http://dx.doi.org/10.17507/tpls.0904.08. Retrieved

http://www.academypublication.com/ojs/index.php/tpls/article/view/tpls0904411423/1875 (accessed on: 24/03/ 2019).

[19] Hosseini, S.M.H. (2019). Dr Hosseini's Catalyst for Transformation and Change. Germany: Scholar's Press Publishing.

[20] Jacobs, G. (1988). Cooperative goal structure: A way to improve group activities. ELT Journal, 42(2), 97-100.

[21] Jacobs, \& A., C. DaSilva Iddings, (Eds.). Cooperative learning and second language teaching. New York: Cambridge University Press.

[22] Jahanbazian, T. (2015). A study into the effects of 'Competitive Team-Based Learning' and 'Learning Together' on the oral performance of intermediate EFL Learners. Iranian Journal of Research in English Language Teaching, 3, 60-73. Retrieved from http://relp.khuisf.ac.ir/article_533624_3a87dbba748748e68ba1f08bc20cd106.pdf (accessed on: 24/01/ 2019).

[23] Jahanbazian, T. (2015 b). A Study into the Effects of Competitive Team-Based Learning and Learning Together on the Oral Performance of Intermediate EFL Learners. Unpublished MA Thesis, Kohgiloyeh And Boyer Ahmad Islamic Azad University, Iran.

[24] Jahanbazian, T. (2015). Competitive team-based learning in conversation classes. Germany: Scholar Press.

[25] Johnson, D. W., Johnson, R. T., \& Smith, K. A. (1998). Active learning: Cooperative learning in the college classroom. Edina, MN: Interaction Book Company.

[26] Konpan, T. (2006). A comparison of reciprocal teaching technique and communicative teaching technique in developing Mattayom Suksa 4 Students' Reading Comprehension. Unpublished master dissertation, Srinakarinwirot University, Thailand.

[27] Nederhood, B. (1986). The effects of student team learning on academic achievement, attitudes towards self and school, and expansion of friendship bonds among middle school students. Dissertation Abstract International, 47(4), 1175A. (DAR R OF LIT)

[28] Ning, H. (2011). Adapting cooperative learning in tertiary ELT. ELT Journal, 65(1), 60-70.

[29] Pearson, P. D., \& Fielding, L. (1991). Comprehension instruction. In R. Barr, M. Kamil, P. Mosenthal, \& P. D. Pearson (Eds.), Handbook of reading research: Volume II (pp. 815-860). White Plains, NY: Longman Publishing.

[30] Palincsar, A.S., \& David, Y.M. (1990). Learning dialogues for comprehension and knowledge acquisition. Paper presented at the annual meeting of the Council for Exceptional Children, Toronto.

[31] Pattanpichet, F. (2011). The Effects of using collaborative learning to enhance students'English speaking achievement, Journal of College Teaching \& Learning, 8(11), 1-10. 
[32] Richards, J.C., Hull, J. and Proctor, S. (2005). Interchange ( $3^{\text {rd }}$ ed.). New York, Cambridge University Press.

[33] Rosenshine, B., \& Meister, C. (1994). Reciprocal teaching: A review of the research. Review of Educational Research, 64, 479-531.

[34] Salari, F. (2018). The Effect of Competitive Team-Based vs. Reciprocal Program in Reading Comprehension Ability of Iranian EFL Learners. Unpublished MA Thesis, Quchan Islamic Azad University, Iran.

[35] Salimi Bani, K. (2017). The effect of competitive team-based learning and cooperative integrated reading and composition on the reading comprehension of Iranian intermediate EFL learners. Unpublished MA Thesis, Khorasgan (Isfahan) Islamic Azad University.

[36] Sharan, Y. \& Sharan, S. (1990). Group investigation expands cooperative learning. Educational Leadership, 47(4), 17-21.

[37] Slavin, R. (1995). Cooperative learning: Theory, research, and practice. Massachusetts: Allyn and Bacon.

[38] Westera, J., \& Moore, D. (1995). Reciprocal teaching of reading comprehension in a New Zealand high school. Psychology in the Schools, 32(3), 225-232.

[39] Wisaijorn, P. (2003). Teaching reading comprehension to Thai EFL students: Reciprocal Teaching Procedure. Unpublished thesis, University of Canberra, Canberra, Australia. Retrieved April 21, 2015, from http://adt.caul.edu.au/homesearch/find/?recordid=131086.

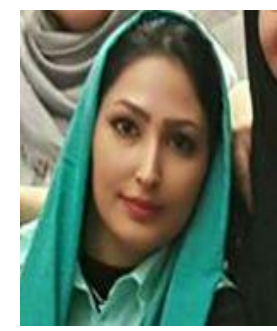

F. Salari received her MA in English language teaching from Azad University in 2018. She is, at present, teaching in different language institutes in Mashhad, Iran. She is interested in innovative methods and approaches to language teaching.

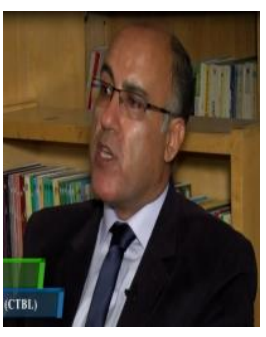

S. M. H. Hosseini, as an Iranian liberal educator, is interested in democratic education and has a zest for awakening, empowering, and emancipating the oppressed majority. He succeeded to publish more than 150 bookticles during his stay in India, in the course of pursuing his PhD, in ELT. Dr Hosseini has suggested language as a liberating agent in his seminal Cognitive Socio-Political Language Learning Theory based upon which he introduced his instructional weapon, a weapon for the overthrow of dictatorial regimes. Particularly, he recalibrates the critical attitude of his mind towards the philosophy beyond curricula in corrupt regimes and he focuses upon the importance of his didactic weapon for educators in today world context of tyranny. Although Dr Hosseini has the experience of teaching in different universities both in Iran and overseas, he has been obliged to teach at a school for backward students in Mashhad. 